\title{
Library and Information Science Research 2002-2003:
}

\section{A Bibliography of Master's Papers from the University of North Carolina School of Information and Library Science}

The following master's papers were submitted in partial fulfillment of the requirements for the master of science in library science degree or the master of science in information science degree at the School of Information and Library Science at the University of North Carolina at Chapel Hill. The subject headings used to index them have been given. The master's papers are available for interlibrary loan.

Bachtell, Matthew. "Advertising of Extensible Markup Language (XML) Online Public Access Catalogs (OPACs): A Case Study Involving Three Library Vendors' Products." Apr. 2003. 36 pages.

Headings: OPAC; XML; MARC; MARC XML; Library vendors.

Barton, Jacqueline A. "Promoting Information Literacy: An Evaluation of the Library's Collaboration with the First-year English Program at UNC-Chapel Hill." Apr. 2003. 46 pages.

Headings: Bibliographic instruction-College and university students; Information Services-North Carolina; Use studies-College and university libraries.

Bauers, Anne. "Interaction Techniques for Large Digital Images: A Comparative Study. Apr. 2003. 59 pages.

Headings: User interface design-Usability; Human computer interaction; Digital images; Application software-Development.

Boothman, Sean M. "The School of Information and Library Science Information Technology Recovery Plan." May 2003. 102 pages.

Headings: Security--Business continuity; Policies--Information technology recovery.

Britto, Kathleen. "The American Homefront of World War II in Literature for Children: An Evaluative Comparison of Series and Autobiographical Fiction." Apr. 2003. 58 pages.

Headings: Children's literature-Series; Children's literature-United States; Historical fiction—Evaluation; Children's literature-Evaluation; World War, 19391945.

Bull, Anthony. "Alumni Online Plus: An Online Community for Professional Networking." Apr. 2003. 95 pages.

Headings: Alumni relations-Online communities—Design; Alumni relations online communities-Implementation; Information systems-Education- 
Alumni relations; Career services-Online services—Design; Career servicesOnline services-Implementation; Web programming-PHP/MySQL.

Bullard, Kristen A. "Virtual Reference Service Evaluation: An Application of Unobstrusive Research methods and the Virtual Reference Desk's Facets of Quality for Digital Reference Service." Apr. 2003. 80 pages.

Headings: College and university libraries-Reference services-Evaluation; Reference services-Evaluation; Reference services-Automation-Evaluation; Reference services-Standards; Carnegie Foundation for the Advancement of Teaching; Virtual Reference Desk.

Daniel, Linda L. "The Effects of Email on an Academic Library's Reference Service." Apr. 2003. 64 pages.

Headings: Academic libraries_Reference services; Electronic mail messages; Electronic reference services (Libraries).

Epps, William. "Questioning Chat: A Study of the Types of Questions Asked through Chat Reference." Apr. 2003. 23 pages.

Headings: College and university libraries-Reference services; Reference services-North Carolina; Academic libraries—Reference services; Electronic reference services; Reference services-Automation.

Fernandez, Michael. "A Usage Comparison for Print and electronic Books in the University of North Carolina at Chapel Hill." Apr. 2003. 48 pages.

Headings: Use studies—Electronic books; College and university libraries—Book collections; College and university libraries-Collection development.

Getz, Elizabeth A. "Looking to the High Ground: Historians at the Fredericksburg and Spotsylvania National Military Park Respond to FY-2000." Apr. 2003. 57 pages.

Headings: Exhibits and displays—Special subjects-Slavery; Information systems_-Special subjects-American studies; Museum-library relations; United States-History-1861-1865 (Civil War) -Exhibits and displays; United StatesNational Park Service.

Graham, Rachel. "Gender Role Reinforcement in Popular Magazine Advertising." April 2003. 27 pages. MP2829.

Headings: Advertising, Magazine-United States; Men's magazines; Sex role in advertising; Women's periodicals, American.

Graves, Michael J. "Concert Event Metadata: Describing concerts Effectively in a Digital Environment." Apr. 2003. 38 pages.

Headings: Metadata; Music; Ontologies; Resource Description Framework; Web Ontology Language.

Gresko, Amy Beth. "Recruitment to the Profession: Student Workers in Academic Libraries as Potential Future Librarians." Apr. 2003. 40 pages.

Headings: College and university libraries; Librarians-Supply and demand; Recruiting for librarianship; Student assistants—College and university libraries.

Haggard, Alisa F. "The Process of Writing an ITU-T Recommendation for SIP Endpoint Directory Services." Apr. 2003. 108 pages.

Headings: Computer network resources; Directory services-Computer network technology; Videoconferencing; International Telecommunications Union.

Hallyburton, Ann. "Your Way, My Way, Our Way: A Critical Perspective of Young Adult Disability Fiction Since the Civil Rights Era." Apr. 2003. 109 pages.

Headings: Disability studies; People with disabilities in literature; Young adult literature-History and criticism.

Hassett, Robert E. "The Chapel Hill Linux Lab: A Case Study in the Use of Linux and Other Open Source Applications in the High School Setting." Nov. 2002. 18 pages. 
Headings: Client server computing; Linux operating system; MicrocomputersEquipment; Open source software.

Heimbuack, Susan T. "Children's Librarians' Perceptions of Computers in the children's Section of the Public library." Apr. 2003. 49 pages.

Headings: Computers and children; Children's libraries-North Carolina; Public libraries-North Carolina.

Intrator, Miriam. "Avenues of intellectual Resistance in the Ghetto Theresienstadt: Escape through the Ghetto Central Library, Reading, Storytelling and Lecturing." Apr. 2003.

Headings: Theresienstadt (Concentration camp); Theresienstadt (Concentration camp)—Literary collections; Holocaust, Jewish (1939-1945)—CzechoslovakiaPersonal narratives; Holocaust, Jewish (1939-1945)—Literary collections; World War, 1939-1945-Jewish resistance.

Irvin, Kristina M. "Comparing Information Retrieval Effectiveness of Different Metadata Generation Methods." Apr. 2003. 28 pages.

Headings: Metadata; Professionally generated Metadata; Automatically generated Metadata; Information retrieval.

Jiang, Yanfang. "The ALISE Project: Design of an Online Questionnaire for Integration and Processing of Statistical Information." Jan.2003. 149 pages.

Headings: Online survey—Design; Database-Management—Systems; Information system-Design; Interface design; Web databases.

Li, Meichun. "Design and Implementation of a Database-Driven Web-Based Student Evaluation and Tracking System for the Emergency Medicine Department of University of north Carolina at Chapel Hill." Apr. 2003. 62 pages.

Headings: Database-Management-Systems; Information system-Design; Interface design; Web databases.

Liu, Lu. "The University Center for International Studies: International Faculty Expertise Online Database Project." Apr. 2003. 37 pages.

Headings: Database-Management—Systems; Databases_-Information storage and retrieval; Information systems-Design; Web databases-Design.

Lu, Dihui. "Biologists' Information Seeking Behavior with Online Bioinformatics Resources for Genome Research." Jan. 2003. 44 pages.

Headings: Bioinformatics; Biologists; Surveys; Information seeking.

McClusky, Anne. "Barriers to Educational Use of Digitized Primary Source Documents: A Survey." Apr. 2003. 31 pages.

Headings: Digital libraries_-United States; Educational technology_Electronic records; Digitized archives; Education-Primary sources.

Mojuetan, Obire. "The Office of Student Counseling's Database Project." Apr. 2003. 37 pages.

Headings: Database-Management—Systems; Systems analysis; User interfaceDesign; User interface-Analysis.

Park, Ok Nam. "An Empirical Study of the Impact of Subject headings on Information Performance-Investigation of Nursing Domain Users." Apr. 2003. 60 pages. Headings: Subject headings; Keywords; Search performance; Medline; Medical Subject Headings (MeSH); Nursing domain users.

Pittman, Leigh B. "The Role of the Elementary School Library in North Carolina's Character Education Curriculum." Apr. 2003. 52 pages.

Headings: School libraries-Character education; School libraries-North Carolina; Reading and morals; Ethics.

Pohl, Ingrid A. "Advocacy on the Web: An Evaluation of a Nonprofit Advocacy organization's use of the Web to Support Its Mission and Goals." Apr. 2003. 62 
pages.

Headings: Web sites-Evaluation; Web sites-Aims and objectives; Use studiesInternet; Nonprofit organizations; Advocacy organizations.

Preston, Elizabeth Earle. "The Society of American Archivists, Graduate Archival Education, and Progress: A Study of the History of Archival Education and Current Curricula." Apr. 2003. 44 pages.

Headings: Archivists-Education; Curricula; Professional education; Society of American Archivists.

Runkle, Rachelle A. "Decisions, Decisions: A Content Analysis of Audiobook Reviews as Aids to Collection Development." Apr. 2003. 52 pages.

Headings: Audiovisual materials—Collection development; Audiovisual materials—Content analysis; Audiovisual materials—Reviews; Talking books-History.

Sanders, Mark M. "Saving El Universal: A Case Study in Evaluation and Preservation of a Historic Latin American Newspaper." Apr. 2003. 40 pages.

Headings: College and university libraries; Collection evaluation; Newspapers; Preservation of library materials; Latin America.

Segedy, Steve. "Digitizing The Appalachian Folklife Project." Apr. 2003. 34 pages. Headings: Digitization-Multimedia digitization; Metadata-Standards; Archiving-Digital museum archiving.

Sievers, Melissa A. "Brains, Brawn and Breasts: How Women Are Depicted in Today's Action/Adventure Comic Books." Apr. 2003. 64 pages.

Headings: Comic books, strips, etc.; Comic books, strips, etc.-Women; Comic books, strips, etc.-Evaluation; Women in literature.

Sizemore, Donald. "ibibliometrics: Measuring Ten Years of Free=Range Academic Web Publishing." Mar. 2003. 40 pages.

Headings: Information systems; Digital libraries; Bibliometrics; Publishing trends.

Spackman, Elizabeth. "The Role of Recreational Reading in High School Media Centers: Four Case Studies." Apr. 2003. 50 pages.

Headings: Reading incentive programs; School libraries-Book programs; School libraries-High schools; School libraries—North Carolina.

Spinks, Richard. "Portal Resources Information System: The Design and Development of an Online Database for Tracking Web Resources." Apr. 2003. 27 pages. Headings: Web—Databases; Online_-Databases; Databases; Information systems-Design.

Stevenson, Nicole. "Will You Return Home?: A Study on the Utility of navigational Aids." Apr. 2003. 63 pages.

Headings: World Wide Web—Navigational aids; World Wide Web—Usability; Websites-Evaluation.

Stone, Wayne. "WEBSITE LOG ANALYSIS: Case Study of USA Cycling's Website." Nov.2002. 78 pages.

Headings: Internet-USA Cycling; Internet-Statistics; use studies-Internet; Web sites-Case studies; World Wide Web-Statistics.

Tardiff, Melissa. "Methods Ten Year Olds Use To Select Reading Material." Apr. 2003. 31 pages.

Headings: Children-Book selection; Book selection-Children; ChildrenReading habits.

Tinker, Gary. "Protocols and Methodologies for the Utilization of MPEG-7 in Multimedia Data Storage and Retrieval." Dec. 2002. 44 pages. Headings: MPEG-7; Multimedia metadata; Feature extraction. 